\title{
Estimation of Production Function of Hiunde (Boro) Rice
}

\author{
Ram B. Bhujel ${ }^{1 *}$ and Surya P. Ghimire ${ }^{1}$ \\ ${ }^{1}$ Regional Agriculture Research Station, Tarahara, Sunsari, Nepal
}

\begin{abstract}
Hiunde (Boro) rice has not been popularized due to least attention given to this crop in Nepal. In order to estimate the production function of this crop, a field survey in Morang district during $2002 / 2003$ was carried out using a semi-structured questionnaire. The primary information was collected through face to face interview. The result of the empirical model of Cobb-Douglas production function revealed the model significant at $1 \%$ level and defined $95 \%$ variation in Hiunde rice production due to variation in independent variables included in the model. The coefficient of area, nitrogen, phosphorous, and tractor hour were found significant at $1 \%$ level while the dummy for more than 10 times of irrigation was significant at 5\% level and up to 10 times of irrigation and potash was significant at $10 \%$ level. The effect of human and bullock labor was found non-significant. Among the sampled farmers the average cropping intensity was $194 \%$ and average yield of Hiunde rice was $4802.50 \mathrm{~kg} / \mathrm{ha}$. On an average $131 \mathrm{~kg}$ of nitrogen, phosphorous and potash was applied for one ha and 15 irrigations in average. The net benefit from Hiunde rice was found to be Rs. 14507.41/ha with 1.73 benefit cost ratio. About $31 \%$ cost was incurred in land preparation and transplanting which was highest among the operations. It was followed by the costs incurred in fertilizers and agrochemicals which counted $23 \%$.
\end{abstract}

Key words: Estimate, Hiunde rice, production function

\section{INTRODUCTION}

Agriculture is the mainstay of Nepalese economy which is continued to be dependent upon monsoon rainfall due to lack of sufficient irrigation facilities. The average annual economic growth rate of agriculture sector was estimated to be $3.3 \%$ as against the target of $4 \%$ during the period of Ninth Plan while this target is $4.1 \%$ per annum during Tenth Plan (MoF 2003). The average annual growth rate of paddy production during Ninth Plan was $2.34 \%$ while for yield it was $2.26 \%$ (ABPSD 2003). Rice is a major staple food crop which contributes more than $50 \%$ to total edible cereal production and about $20 \%$ to agriculture domestic product (AGDP) in the country. During 2003/2004, the preliminary estimation has predicted $50.15 \%$ contribution of rice to total edible cereal grain requirement (ABPSD 2004). The surplus production was in eastern and western region while other three regions were in food deficit status.

Paddy during 2003/2004 was grown in 1559436 ha which produced $4455722 \mathrm{mt}$ with an average yield of $2857 \mathrm{~kg} / \mathrm{ha}$ (ABPSD 2004). The improved varieties covered about $83 \%$ area which was about $46 \%$ under irrigated and about $37 \%$ under unirrigated environment. The net profit from one ha of rice cultivation during 2002/2003 under improved and irrigated condition in Tarai belt was Rs 9524.00/ha while it was Rs 10500.00 for hills (DoEAS 2004).

Rice in Nepal is mostly grown in two distinct seasons; main/summer season (June/JulyOctober/November) and early/Chaite/Autumn rice (March/April-May/June). Except these two season crops, farmers are also growing rice as Hiunde Dhan (Boro) on winter in certain parts of the country. They had started rice cultivation in winter (November/December-May/June) season in Kawasoti Village Development Committee (VDC) of Nawalparasi district since 1968 (Joshi 2004). Other VDCs growing Hiunde rice in Nawalparasi district are Angeli and Pithauli. The winter rice cultivation has been 
introduced in Benauli and Sira Ineruwa VDC of Bara district; Biruwaguthi, Madhuwan (Auraha) VDC of Parsa district (Personal communication with KP Bhurer, RARS, Parwanipur, Bara); Parwaha, Nikal (Sapahi), and Sakhuwa Mahendranagar (Pakadia) VDC of Dhanusa district (Personal communication with Dr N Adhikari and RB Yadav, NRRP, Hardinath, Dhanusha). Despite theses areas, Morang is a leading district in winter rice cultivation where Rangeli, Aampgachhi, Takuwa and neighboring VDCs are major pocket areas. It is also grown in Mahabhara VDC of Jhapa district. Though the official statistics on area of winter rice is not available, the area covered by this crop is estimated to be more than 400 ha in Nepal (Bhujel 2004).

Winter rice in Nepal is generally called as Hiunde Dhan while in India and Bangladesh it is popularly known as 'Boro Rice'. Boro - a Bengali term originated from the Sanskrit word 'BOROB'. It refers to a special cultivation of rice in low land pockets during November-May; taking advantage of the residual water in the field after harvest of Kharif season paddy, longer moisture retentivity of the soil and surface water stored in the near by ditches (Singh et al 2003a). Thakur et al (2003) reported Boro in Shivapuran as one of the offerings to the God. In Bangladesh rice is grown in three distinct seasons; boro (January to June), aus (April to August), and amon (August to December). Modern rice varieties were introduced for the boro and aus seasons in 1967 and for the amon seasons in 1970 (Hossain et al 1994). In Bangladesh boro rice occupied nearly $35 \%$ of the 10.80 million ha of rice harvested area, and contributed $50 \%$ of the 38.7 million tons of rice produced in 2001/2002. The yield in 2001/2002 was 4.9 ton/ha (Singh et al 2003b).

In India it is commonly grown in the deeply flooded areas of North East Bihar, West Bengal, Assam and Eastern Uttar Pradesh. Pusa 2-21, IR 8, Jaya etc. became popular varieties (Thakur et al 2003). In Madhubani District, substantial increase in farm income was observed due to boro farming which made the distribution more equitable particularly on small farm households. Boro rice production helped in increasing employment, particularly in slack agricultural season. It has brought about a change in socioeconomic status of rural households (Nilanjali and Singh 2003). The net return to the farmers from the cultivation of boro in Bangladesh during 2000 was about US \$ 433/ha, almost eight times higher than that from aus and about three times compared to the return from wheat (Hossain 2003).

The estimation of production function of winter rice in eastern region of the country has not been found sufficiently studied and its socio-economics study is also lacking. Considering these facts a primary level study on winter rice was carried out during 2059/2060 (2002/2003). The main objective of this study was to estimate production function.

\section{METHODOLOGY}

Morang being a leading district in winter rice cultivation was selected for the study. The popular VDCs for winter rice cultivation in Morang district like Rangeli, Aampgachhi and Takuwa were purposively selected as these are the major pocket areas of this crop. A sampling frame of winter rice growers was prepared and 35 farmers were selected randomly without replacement. The primary information was collected from sample farmers through face to face interview schedule. A standardized semi-structured questionnaire was finalized after pre-testing and interview carried out. The secondary data were collected from published documents and personal communication with related agencies.

\section{Empirical model}

The empirical model used in this study was the Cobb-Douglas production function and other simple statistical tools like mean, total count and percent. This model was selected because; among the production functions, the power production function is a new linear production function which is also known as Cobb-Douglas production function after the name of the persons who first applied it in empirical works (Debertin 1986, Sankhayan 1988). This function has been widely used in agricultural 
studies because of its simplicity. Furthermore, this function allows either constant, increasing or decreasing marginal productivity, or not all the three and even any two at the same time.

The model specified was:

$\mathrm{Y}=\mathrm{AX}_{1}{ }^{\mathrm{b} 1} \mathrm{X}_{2}{ }^{\mathrm{b} 2} \mathrm{X}_{3}{ }^{\mathrm{b} 3} \mathrm{X}_{4}{ }^{\mathrm{b} 4} \mathrm{X}_{5}^{\mathrm{b} 5} \mathrm{X}_{6}{ }^{\mathrm{b} 6} \mathrm{X}_{7}{ }^{\mathrm{b} 7} \mathrm{D}_{1}{ }^{\mathrm{b} 8} \mathrm{D}_{2}{ }^{\mathrm{b} 9} \mu$

Where,

$\mathrm{Y}=$ Production of winter rice $(\mathrm{kg}), \mathrm{A}=$ Intercept, $\mathrm{X}_{1}=$ Area of winter rice (ha), $\mathrm{X}_{2}=$ Human labor $(\mathrm{Man}$ days), $X_{3}=$ Bullock labor (Labor days), $X_{4}=$ Nitrogen $(\mathrm{kg}), X_{5}=$ Phosphorous $(\mathrm{kg}), X_{6}=$ Potash $(\mathrm{kg})$, $\mathrm{X}_{7}=$ Tractor hour, $\mathrm{D}_{1}=$ Dummy for number of irrigation (1 for up to 10 irrigations, and 0 for otherwise), $\mathrm{D}_{2}=$ Dummy for number of irrigation (1 for more than 10 irrigations, and 0 for otherwise), $b_{1}$ to $b_{9}=$ Elasticities coefficients, $\mu=$ Error term

Above model can be estimated by using Ordinary Least Square (OLS) method. The Cobb-Douglas Production Function was transferred into log-linear form as:

$\ln Y=\ln A+b_{1} \ln X_{1}+b_{2} \ln X_{2}+b_{3} \ln X_{3}+b_{4} \ln X_{4}+b_{5} \ln X_{5}+b_{6} \ln X_{6}+b_{7} \ln X_{7}+b_{8} D_{1}+b_{9} D_{2}+\mu$

The values of the input coefficients imply their contribution to the production of winter rice or the coefficients are the level of determination to winter rice production.

\section{RESULTS AND DISCUSSION}

The primary information was collected from 35 farmers and only 33 were valid for final analysis due to outlier nature of certain information. The calculation was done for farm size, cropping intensity, yield, labor (human and bullock), quantity of inputs and cost incurred in different operations for the cultivation of winter rice. Similarly, the share of inputs for different operations was also calculated.

\section{Sowing and harvesting time}

The response of sample farmers revealed the popular sowing time for winter rice as Kartik-Mangsir (November-December) for seeding, Magh (January/February) and latest by first week of Falgun was the suitable time for transplanting, while Jestha (May/June) and latest by the first week of Ashadh was the period when most of the farmers harvested the crop. The most popular variety grown by the farmers was Jaya which was supposed to be introduced from neighboring part of Bihar, India. The variety was not replaced and continued to be used from generation to generation.

\section{Farm size}

Among the sample farmers the average operational holding was 5.08 ha and the distribution of more than 0.67 ha to 3 ha holding was high showing the $40 \%$ farmers within this status (Table 1 ).

Table 1. Average farm size of winter rice growers in Morang District

\begin{tabular}{llrr}
\hline SN & Operational hectare & Number of farmers & Percent \\
\hline 1 & Up to 0.67 & 1 & 3 \\
2 & $>0.67-3$ & 13 & 40 \\
3 & $>3-5$ & 9 & 27 \\
4 & $>5-7$ & 6 & 18 \\
5 & $>7$ & 4 & 12 \\
\hline
\end{tabular}




\section{Cropping intensity}

Farmers were not much interested to grow wheat or early rice during this season and very few were found growing wheat and Chaite rice along with winter rice during a period of one year. However, the cropping intensity was found to be $194 \%$ in average. More than $48 \%$ farmers were found to have more than 150 to $200 \%$ cropping intensity (Table 2 ).

Table 2. Average cropping intensity of winter rice growers in Morang District

\begin{tabular}{llrr}
\hline SN & Cropping intensity, \% & Number of farmers & Percent \\
\hline 1 & Up to 150 & 5 & 15 \\
2 & $>150-200$ & 16 & 48.5 \\
3 & $>200-250$ & 7 & 21 \\
4 & $>250$ & 5 & 15.5 \\
\hline
\end{tabular}

\section{Yield}

The farmers were very much enthusiastic to achieve high yield from winter rice, however, the average yield recorded from sample farmers was $4802.5 \mathrm{~kg} / \mathrm{ha}$. The majorities of the sample farmers $(21.21 \%)$ produced $3700-4200 \mathrm{~kg} / \mathrm{ha}$, while more than $18 \%$ farmers were found producing more than $5700 \mathrm{~kg} / \mathrm{ha}$ average yield (Table 3). Only $3 \%$ farmers produced up to $2700 \mathrm{~kg} / \mathrm{ha}$.

Table 3. Average yield of winter rice among the sample farmers in Morang District

\begin{tabular}{llrr}
\hline SN & Average yield, $\mathrm{kg} / \mathrm{ha}$ & Number of farmers & Percent \\
\hline 1 & Up to 2700 & 1 & 3.03 \\
2 & $>2700-3700$ & 3 & 9.09 \\
3 & $>3700-4200$ & 7 & 21.21 \\
4 & $>4200-4700$ & 1 & 3.03 \\
5 & $>4700-5200$ & 5 & 15.15 \\
6 & $>5700$ & 6 & 18.18 \\
\hline
\end{tabular}

\section{Seed rate}

Among the sample farmers $85 \mathrm{~kg} / \mathrm{ha}$ seed rate was adopted which varied from 72 to more than 157 $\mathrm{kg} / \mathrm{ha}$ (Table 4). The seed rate being high in winter rice is due to high chances of seedling mortality and injury due to cold and slow growth as it has to tolerate natural cold during seeding to seedling stage. Therefore farmers use high seed rate to compensate the anticipated damage of seedlings. Majority of sample farmers were found applying more than 72 to $115 \mathrm{~kg}$ seed/ha and very few were found to sowing more than $157 \mathrm{~kg}$ seed for one ha (Table 4).

Table 4. Average seed rate of winter rice applied by the sample farmers in Morang District

\begin{tabular}{llrr}
\hline SN & Seed rate, $\mathrm{kg} / \mathrm{ha}$ & Number of farmers & Percent \\
\hline 1 & Up to 72 & 10 & 30.30 \\
2 & $>72-115$ & 18 & 54.54 \\
3 & $>115-157$ & 4 & 12.12 \\
4 & $>157$ & 1 & 3.04 \\
\hline
\end{tabular}

\section{Use of nitrogen}

Dia-Ammonium Phosphate (DAP) and urea were found as major sources of nitrogen. The average rate of nitrogen used by sample farmers in survey area was $74.52 \mathrm{~kg} / \mathrm{ha}$. Some of the farmers were also using even more than $100 \mathrm{~kg}$ nitrogen/ha. However, the range between more than $70-90 \mathrm{~kg} / \mathrm{ha}$ application of nitrogen was dominant among the sample households (Table 5). The range of more than 90 to $100 \mathrm{~kg}$ nitrogen/ha was lowest among the sample farmers which was only $6 \%$. 


\section{Use of phosphorous}

Dia-ammonium phosphate (DAP) was the main source of phosphorous which provides $46 \%$ nutrient phosphorous. The average quantity of phosphorous applied by the farmers was $38 \mathrm{~kg} / \mathrm{ha}$ while the range of its application from more than $30-50 \mathrm{~kg} / \mathrm{ha}$ was applied by $61 \%$ of the sample farmers (Table 6). Quantity ranging from more than $30-40 \mathrm{~kg} \mathrm{P}_{2} \mathrm{O}_{5} / \mathrm{ha}$ was applied by $42 \%$ of the sample farmers.

Table 5. Average dose of nitrogen applied by the sample farmers for winter rice in Morang District

\begin{tabular}{llrr}
\hline SN & Nitrogen, $\mathrm{kg} / \mathrm{ha}$ & Number of farmers & Percent \\
\hline 1 & Up to $50 \mathrm{~kg}$ & 6 & 18.18 \\
2 & $>50-70$ & 9 & 27.27 \\
3 & $>70-90$ & 12 & 36.36 \\
4 & $>90-100$ & 2 & 6.06 \\
5 & $>100$ & 4 & 12.12 \\
\hline
\end{tabular}

Table 6. Average dose of phosphorous applied by the sample farmers for winter rice in Morang District

\begin{tabular}{llrr}
\hline SN & Phosphorous, kg/ha & Number of farmers & Percent \\
\hline 1 & Up to 30 & 8 & 24.24 \\
2 & $>30-40$ & 14 & 42.42 \\
3 & $>40-50$ & 6 & 18.18 \\
4 & $>50-60$ & 1 & 3.03 \\
5 & $>60$ & 4 & 12.12 \\
\hline
\end{tabular}

\section{Use of potash}

Farmers were applying Muriate of Potash as a main source of potash. The average nutrient potash used by the sample farmers was found $18.58 \mathrm{~kg} / \mathrm{ha}$ and the majority of the farmers applied up to $30 \mathrm{~kg}$ of potash/ha (Table 7 ). Only 3 per cent farmers applied more than $40 \mathrm{~kg}$ potash/ha.

Table 7. Average dose of potash $\left(\mathrm{K}_{2} \mathrm{O}\right)$ applied by the sample farmers for winter rice in Morang District

\begin{tabular}{llrr}
\hline SN & Potash, $\mathrm{kg} / \mathrm{ha}$ & Number of farmers & Percent \\
\hline 1 & Up to 30 & 30 & 90.90 \\
2 & $>30-40$ & 2 & 6.06 \\
3 & $>40$ & 1 & 3.03 \\
\hline
\end{tabular}

The above figure of nitrogen $(\mathrm{N})$, phosphorous $(\mathrm{P})$ and potash $(\mathrm{K})$ made the ratio of $74: 38: 19 \mathrm{~kg}$ NPK/ha counting whole NPK as $131 \mathrm{~kg} / \mathrm{ha}$ on an average. However, the dose of more than 100-130 $\mathrm{kg} / \mathrm{ha}$ was applied by the majority of the farmers counting more than $30 \%$ followed by $27.28 \%$ who were found applying more than $145 \mathrm{~kg} \mathrm{NPK} / \mathrm{ha}$ (Table 8).

Table 8. Average dose of NPK applied by the sample farmers for winter rice in Morang District

\begin{tabular}{llrr}
\hline SN & NPK, $\mathrm{kg} / \mathrm{ha}$ & Number of farmers & Percent \\
\hline 1 & Up to 100 & 5 & 15.16 \\
2 & $>100-130$ & 10 & 30.31 \\
3 & $>130-145$ & 7 & 21.22 \\
4 & $>145$ & 9 & 27.28 \\
\hline
\end{tabular}

\section{Irrigation}

The winter rice is irrigation intensive crop as it needs whole winter season to medium summer season for its life cycle. Without assured irrigation, the production cannot be expected high for this crop. Therefore, the number of irrigation for this crop was found very high in comparison with other winter crops. The average number of irrigation supplied by sample farmers was 15 times while the majority of the farmers were found irrigating winter rice more than 16 to 20 times for whole crop season (Table 9). The high number of irrigation is due to its long period that crosses whole winter season and also the spring season where the crop has to be faced moisture stress condition. To overcome this situation, the irrigation needs to be frequent and regular. More than $9 \%$ of farmers were found irrigating more than 20 times. 
Table 9. Average number of irrigation applied by the sample farmers for winter rice in Morang District

\begin{tabular}{llrr}
\hline SN & Irrigation number & Number of farmers & Percent \\
\hline 1 & Up to 4 & 2 & 6.06 \\
2 & $>4-8$ & 5 & 15.15 \\
3 & $>8-12$ & 5 & 15.15 \\
4 & $>12-16$ & 6 & 18.18 \\
5 & $>16-20$ & 12 & 36.36 \\
6 & $>20$ & 3 & 9.10 \\
\hline
\end{tabular}

\section{Human and bullock labor}

The human and bullock labor in average used by sample farmers of winter rice growers was found 84 man days and 16 bullock pairs/ha, respectively. More than 35 to 70 human labor/ha was used by more than 33\% of sample farmers while more than 14-20 pairs of bullock was used by more than 51\% of sample farmers at survey site (Table 10). The number of human and bullock labor was also determined by the use of tractors by the farmers. Farmers also used/hired tractor for land preparation which determined the number of labors (human and bullock).

Table 10. Average number of human and bullock labor/ha used by sample farmers for winter rice cultivation in Morang district

\begin{tabular}{llrrrrr}
\hline SN & $\begin{array}{l}\text { Number of human } \\
\text { labor/ha }\end{array}$ & $\begin{array}{r}\text { Number of } \\
\text { farmers }\end{array}$ & Percent & $\begin{array}{r}\text { Number of } \\
\text { bullock pair/ha }\end{array}$ & $\begin{array}{r}\text { Number of } \\
\text { farmers }\end{array}$ & Percent \\
\hline 1 & Up to 35 & 6 & 18.18 & Up to 8 & 7 & 21.21 \\
2 & $>35-70$ & 11 & 33.33 & $>8-14$ & 6 & 18.18 \\
3 & $>70-105$ & 9 & 27.27 & $>14-20$ & 17 & 51.51 \\
4 & $>105$ & 7 & 21.22 & $>20$ & 3 & 9.10 \\
\hline
\end{tabular}

\section{Use of tractor}

The sample farmers were also using tractor for land preparation of winter rice which was 1.69 hour/ha on an average. Majority of them used at least for one hour (Table 11). Farmers also used tractor for more than 5 hours/ha. Tractor is generally used by most of the farmers at least for first plowing after which they used bullocks.

Table 11. Average tractor hour used by the sample farmers for winter rice in Morang district

\begin{tabular}{llrr}
\hline SN & Tractor hour/ha & Number of farmers & Percent \\
\hline 1 & Up to 1 & 19 & 57.57 \\
2 & $>1-3$ & 8 & 24.23 \\
3 & $>3-5$ & 3 & 9.10 \\
4 & $>5$ & 3 & 9.10 \\
\hline
\end{tabular}

\section{Estimation of production function}

The share of input variables to winter rice production was estimated by using OLS technique. The value of $\mathrm{F}$ test in OLS estimation indicated that the model is significant at $1 \%$. The value of adjusted $\mathrm{R}^{2}$ is 0.95 which reveals that the model has explained $95 \%$ of total variation in winter rice production due to the variation in area, human and bullock labor, nitrogen, phosphorous, potash, use of tractor and number of irrigations (Table 12). According to Gujrati (1995), the coefficient of determination (adjusted $\mathrm{R}^{2}$ ) is a summary measure that tells how well the sample regression line fits the data. The fit of the model is said to be better the closer is $\mathrm{R}^{2}$ to 1 . Therefore, in this model $95 \%$ variation in winter rice production has been defined by independent variables included in the model. The intercept is significant at $1 \%$ level which implies the level of output when the value of all independent variables is zero. The coefficient of winter rice area is positive and significant at $1 \%$ level which implies that, other factors keeping constant, one per cent increase in area would result in $0.91 \%$ increase in winter rice production. Similarly, ceteris paribus, one per cent increase in phosphorous, potash, tractor use would result into $0.33,0.02$ and $0.02 \%$ increase in production from the use of respective variables. Similarly, irrigation for up to 10 and more than 10 are significant at 10 and 5\% level, which reveals that other factors keeping constant, when 
one per cent irrigation for 10 is increased, the production would be increased by $0.36 \%$ and when it is applied to more than 10 number of irrigation it would result in increasing $0.42 \%$ winter rice production.

The nitrogen effect on production is significant at $1 \%$ level and has negative value which indicates the excess application and the variety which is not much responsive to higher dose of nitrogen, however the dose of phosphorous and potash can be increased. Similarly, the human and bullock labor has not any significant effect in production, but the tractor hour can be increased which can further reduce these labors and make the cultivation cost effective.

Table 12. Estimates of ordinary least square (OLS) technique

\begin{tabular}{llrr}
\hline Explanatory variables & Elasticities & Standard errors & t statistics \\
\hline Intercept & $8.09^{* * *}$ & 0.47 & 17.24 \\
Area, ha & $0.91^{* * *}$ & 0.11 & 8.14 \\
Human labor, days & 0.05 & 0.05 & 0.97 \\
Bullock labor, days & 0.01 & 0.03 & 0.48 \\
Nitrogen, kg & $-0.33^{* * *}$ & 0.12 & -2.64 \\
Phosphorous, kg & $0.33^{* * *}$ & 0.10 & 3.13 \\
Potash, kg & $0.02^{*}$ & 0.01 & 1.93 \\
Tractor use, hour & $0.02^{* * *}$ & 0.009 & 2.68 \\
Dummy for number of irrigation up to $10^{\dagger}$ & $0.36^{*}$ & 0.19 & 1.84 \\
Dummy for number of irrigation $>10^{\ddagger}$ & $0.42^{* *}$ & 0.18 & 2.26 \\
Adjusted $\mathrm{R}^{2}$ & 0.95 & & \\
\hline F value $(9,23)$ & $75.63^{* * *}$ & & \\
Observations & 33 & & \\
\hline
\end{tabular}

***, **, * Significant at 1,5 , and $10 \%$ respectively. ${ }^{\dagger} 1$ for up to 10 irrigations and 0 for otherwise. ${ }^{\ddagger} 1$ for more than 10 irrigations and 0 for otherwise.

\section{Analysis of gross margin}

Application of different inputs was taken as variables and their cost as variable costs. The total variable cost incurred in winter rice cultivation was found Rs 19878.49/ha in average while the gross income from the grain production was found Rs 34385.90 , which counted 1.73 as benefit cost ratio. It provided Rs 14507.41 as net benefit from one hectare of winter rice cultivation (Table 13). The scenario of gross margin was as follows:

Average production of winter rice, $\mathrm{kg} / \mathrm{ha} \quad: \quad 4802.50$

Average price of winter rice, $\mathrm{Rs} / \mathrm{kg} \quad: \quad 7.16$

Gross revenue from grain production, Rs : 34385.90

Total variable cost, Rs $\quad: 19878.49$

Benefit cost ratio : : 1.73

Table 13. Gross margin of winter rice cultivation in Morang District

\begin{tabular}{llrr}
\hline SN & Operations and items & Expenditure, Rs/ha & Percent of total expenditure \\
\hline & Input costs & & \\
1. & Seed & 919.47 & 4.62 \\
2. & Chemical fertilizers and agrochemicals & 4613.29 & 23.20 \\
3. & Land preparation and transplanting & 6095.41 & 30.66 \\
4. & Weeding and harvesting & 4261.641 & 21.44 \\
5. & Irrigation & 3856.69 & 19.41 \\
6. & Land tax and interest & 132.53 & 0.66 \\
\hline & Total variable costs & 19878.49 & 100 \\
& Gross revenue from grain production & 34385.90 & \\
Net profit & 14507.41 & \\
\hline
\end{tabular}


The highest cost incurred was found by land preparation and transplanting which was more than $30 \%$ followed by the costs for chemical fertilizers and agrochemicals (Figure 1) which counted more than $23 \%$.

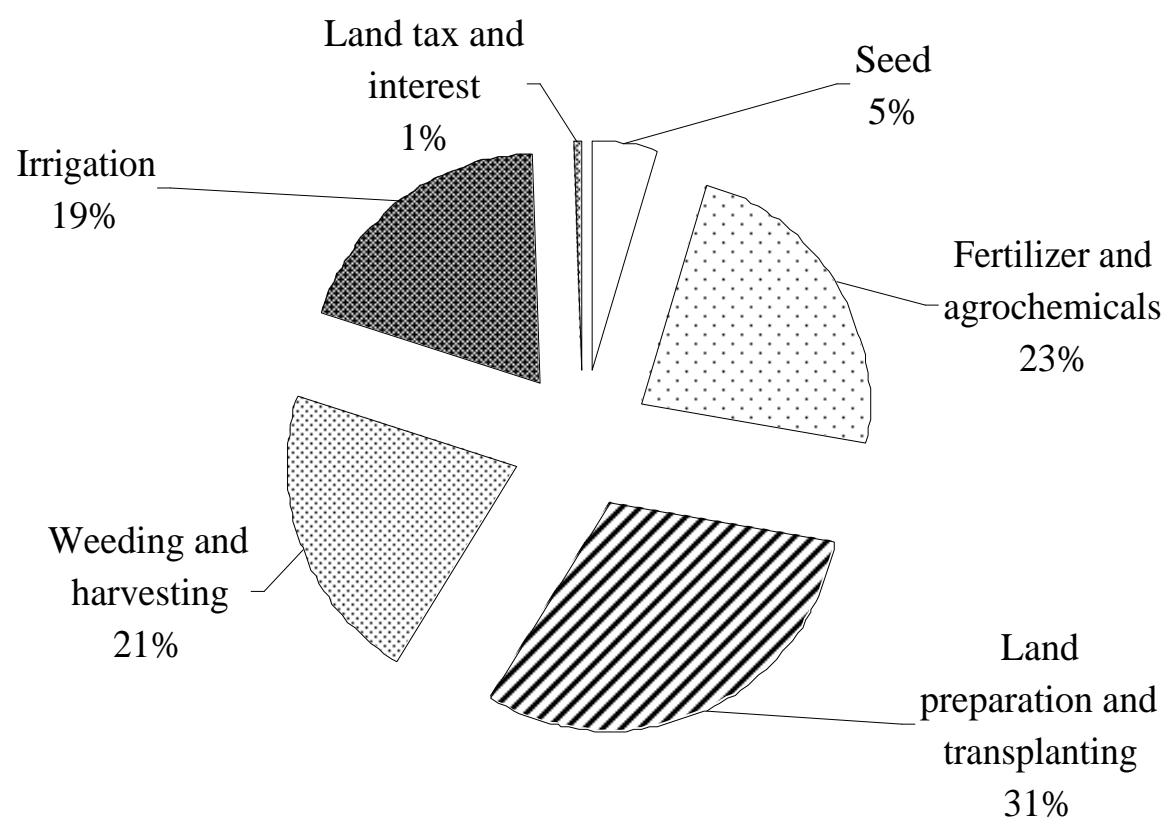

Figure 1. Cost incurred in winter rice cultivation in Morang.

The hypothesis tested was found true that the farmers received more net profit from winter rice in the survey area as benefit cost ratio for this crop was found 1.73. The net profit of Rs 14507.41 is far higher than normal/early rice or wheat crop in the district. It was only Rs 10500.00 and Rs $9524.00 /$ ha from normal rice under irrigated and improved variety in hills and Tarai in 2002/2003.

\section{Why farmers grow winter rice}

On the basis of farmer responses followings are the reasons:

- The production of winter rice is higher than chaite rice and wheat.

- It is harvested before monsoon rainfall and thus it makes the farmer easy to thresh and get rid of disturbance from rainfall as it happens with Chaite rice.

- Due to early harvest, summer rice can be planted in time.

- Majority of the farmers let the straws into the field which adds humus to soil and improve soil health.

- To the date the market problem has not been experienced seriously as the product is sold immediately after threshing (even from the threshing flour) and the fresh grains weigh more due to high moisture content and fetch more money through satisfactory market price. The rice mill owners also get fresh product which is generally used for flat/beaten rice so called Chyura.

- The essence of this crop is that it provides hard cash at the period of Jestha/Ashadh which is/are month/s of crisis for both cash and kind in rural farm households. They are in dire need of resources at this period as there is no any crop to harvest and fetch money. They get relief by earning cash money from winter rice which substantially helps cultivate summer crops, pay school/admission fee of their children and run household activities. Thus winter rice is not only a cereal crop but is 'A hard Cash in Crisis' too (Hiunde Dhan Aapatma Bardan = Winter Rice - Boon in Crisis). 


\section{Problems}

Since the market is available and product is sold out, farmers are satisfied but are in need of high yielding variety that can produce more than presently cultivated Jaya variety. Some of the farmers raised problems on availability and quality of chemical fertilizers and fuels, irregular supply of electricity, and sometimes electric poles/pillars were damaged by storm and were not timely corrected by concerning agencies. They expect encouragement in installing irrigation facilities by government through some subsidy program. Because it is an irrigation-intensive crop and needs more irrigations than any other crop. Quality of inputs was found as a matter of more concerns of the farmers in the survey site.

The cash income earned by the farmers improves their socio-economic status and grows rural economy which can substantially help reduce poverty. The water logged area and the area where excess moisture is exerted in winter season causing unfit for other winter crop can be well utilized by growing winter rice for which a campaign needs to be organized to its extension with package of practices. Migration of rural youth, unemployment and food deficit can be minimized by encouraging winter rice production in the area where it is still not practiced but has its scope and potentiality. Since this was a primary survey, it needs to be carried out in more detail in other rice growing area of the country so as to formulate a proper policy of winter rice in the future.

\section{ACKNOWLEDGMENTS}

Authors are thankful to CR Yadav, RARS, Tarahara for providing facilities to carry out the field survey work. The cooperation extended by the officials of District Agriculture Development Office, Jhapa and Morang is highly acknowledged. KP Bhurer of RARS, Parwanipur Bara, Dr N Adhikari and RB Yadav of National Rice Research Program, Hardinath, Dhanusa are highly appreciated for providing information on winter rice in Nepal. The members of survey team including HK Prasai, AB Thapa, K Mandal and B Yadav deserve special thanks for their cooperation in carrying out survey study in rural villages.

\section{REFERENCES}

ABPSD. 2003. Agriculture sector in the ninth plan. Agri-Business Promotion and Statistics Division, Ministry and Agriculture and Cooperatives, His Majesty's Government of Nepal, Kathmandu. Pp. 6-8.

ABPSD. 2004. Statistical information on Nepalese agriculture, 2003/2004. Agri-Business Promotion and Statistics Division, Ministry and Agriculture and Cooperatives, His Majesty's Government of Nepal, Kathmandu. Nepal. Pp. 4-8.

Bhujel RB. 2004. Rice production challenges in Nepal. NARC News Letter, A special issue on International Year of Rice 2004 (May 2004). CPDD/NARC, Khumaltar, Lalitpur, Nepal.

Debertin DL. 1986. Agriculture production economics. Macmillan Publishing Company, New York, USA. Pp. 166-182.

DoEAS. 2004. Cost of production of cereal crops, Nepal 2059/20600 (2002/2003). MoAC/DoA/Directorate of Economic Analysis and Statistics, His Majesty's Government of Nepal, Harihar Bhawan, Lalitpur. Pp. viiviii.

Gujrati DN. 1995. Basic econometrics. Third edition. McGraw-Hill Inc. Pp. 237.

Hossain M, MA Quasem, MA Jabbar and MM Akash. 1994. Production environment, modern variety adoption and income distribution in Bangladesh. In: Modern rice technology and income distribution in Asia (David and Otsuka, eds). IRRI, Philippines. Pp. 221-279.

Hossain M. 2003. Development of boro rice cultivation in Bangladesh: Trends and policies. In: Boro rice (RK Singh, M Hossain and R Thakur, eds). IRRI-India Office. Pp 25-49.

Joshi BK. 2004. Hiunde Rice: 35 years old practice in Nepal. NARC News Letter, A special issue on International Year of Rice 2004 (May 2004). CPDD/NARC, Khumaltar, Lalitpur, Nepal.

MoF. 2003. Economic survey, Fiscal Year 2002/2003. Ministry of Finance, His Majesty's Government of Nepal. Pp. 113. 
Nilanjali and RKP Singh. 2003. Impact of boro rice cultivation on socio-economic status of farm households in Bihar. In: Boro rice (RK Singh, M Hossain and R Thakur, eds). IRRI-India Office. Pp. 207-220

Sankhayan. 1988. Introduction to the economics of agricultural production. Prentice Hall of India, Pvt. Ltd. New Delhi. Pp. 135.

Singh PK, M Hossain and R Thakur. 2003a. In: Boro rice (RK Singh, M Hossain and R Thakur, eds). IRRI-India Office.

Singh RK, R Thakur and SD Chatarjee. 2003b. Harnessing boro rice potential for increasing rice production in deepwater areas of Eastern India, An overview. In: Boro rice (RK Singh, M Hossain and R Thakur, eds). IRRI-India Office. Pp. 51-72.

Thakur R, NK Singh, VK Chaudhary. 2003. Recent advances in boro rice research in Bihar. In: Boro rice (RK Singh, M Hossain and R Thakur, eds). IRRI-India Office. Pp. 99-116. 